\title{
Comparison of Emerson and Hafiz Based on Claudio Guillen's Comparative Literary Theory of Influence
}

\author{
Saber Noie \\ Department of English Translation, Faculty of Persian Literature and Foreign Languages, Islamic Azad \\ University, Iran, Tehran \\ saber.noie@yahoo.com
}

\begin{abstract}
The poetry of Khajeh Mohammad Hafiz Shirazi has vastly influenced the poetry of Ralph Waldo Emerson, as many critics have noted but have not demonstrated. Emerson is an American poet whose work reflects the influences of Persian poets, among which that of Hafiz is remarkable. The influence of Hafiz on Emerson includes memorable images, themes and motifs. While one can argue that this influence was indirect, it is obvious from the closeness of certain similarities, from Emerson's intimate knowledge of Hafiz's poetry, and from his love for Persian poetry, that the influence was more direct than otherwise. Although Emerson knew German and read Hafiz in German translations yet, he embarked on translating the poems of Hafiz in English in order to master Hafiz's poetry and to introduce him to American readers. These translations themselves are another proof of the claim of influence of Hafiz on Emerson. The methodology of this article is to set the poems of the two poets over against one another and study them watchfully in order to demonstrate the influence of the precursor poet on the belated poet. Therefore the sources of familiarity of Emerson with Hafiz must not be forgotten and should be brought to the surface.
\end{abstract}

Keywords : Emerson; hafiz; image; influence; motif; poet; theme

\section{Introduction}

The aim of this article is to demonstrated the influence of an Iranian poet upon an American poet and for that reason show how Persian poetry can be influential and a matter of pride for modern Persian students and scholars who are not cognizant of this richness of Persian poetry in general and Hafiz in particular. Of course we know Hafiz is great, but his greatness intensifies when we see that he exerted an immense influence upon another poet of especially foreign culture. And knowing this can be a source of pride for Persian readers, researcher, and scholars. Because the nature of this study is comparative which copes with literary influence, it bases its methodology of comparison between Emerson and Hafiz based on Claudio Guillen's comparative literary theory of influence which belongs to French school of comparative analysis. Guillen's theory reinforces the study because it defines the attributes of literary influence; it also functions as a yardstick for assessing the contribution of the recipient of influence to his national literature and to the work of his precursor.

In order to discuss the influence of Hafiz on Emerson we ask the following questions. Did Emerson know how to read Persian? Why did he like or find Hafiz interesting? What arena of Hafiz's poetry was? What made Emerson interested in Hafiz? Did Emerson know about Persian culture and poetry in general? These are the questions which in discussing the influence of a poet on another should be raised and answered in order to see whether we can find the influence of the one upon the other

As far as we know, Emerson did not know how to read Persian. Even he did not try to learn Persian. So how did he come to appreciate Hafiz? He was so attracted to Hafiz that he almost immediately got a copy of Von Hammer-Purgstall's German translation. For 
Emerson, Hafiz became a perfect poet whom he considered a 'poet for poets' and 'the prince of Persian poets.' For fourteen years Emerson read and studied Hafiz and quoted him on multiple occasions including in his essays, Fate, Power and Illusions. Of Hafiz he says: "The ... merit of Hafiz is his intellectual liberty, which is a certificate of profound thought. We accept the religions and politics into which we fall, and it is only a few delicate spirits who are sufficient to see that the whole web of convention is the imbecility of those whom it entangles,-that the mind suffers no religion and no empire but its own" (Gougeon, 1989).

In his article entitled "Emerson and the Bardic Tradition" Adkins writes: In 1869 Emerson was planning a new course of lectures in which, among other things, he aimed to show the difference between good poetry and what passes for good. One topic to be touched on was the "Welsh genius," which had recently aroused his enthusiasm through the reading of Skene's new book. The Welsh poet he finds "far more suggestive, contagious, or I will say, more inoculating the reader with poetic madness, than any poet I now think of, except Hafiz (Adkins, 1948).

So for Emerson, Hafiz is good and genuine poetry. This is what and how Emerson found Hafiz. Yohannan believes that the influence of Persian poetry mostly Hafiz can be traced in the "actual correspondence of thought and of expression between Emerson and the Persian poets; in a similarity of form between Emerson's verse and the German renditions of Joseph von Hammer which he read; and in Emerson's concept of the ideal poet". Hafiz's poetry served to free Emerson's thought from the fetters and limitations of convention and it helped enhance the store of imagery by which he expressed his thought. In American Traits he says: the expressiveness which is the essence of the poetic element, they [the British] have not. It was no Oxonian, but Hafiz, who said, "Let us be crowned with roses, let us drink wine, and break up the tiresome old roof of heaven into new forms (Yohannan, 1943a). Thematically, for Emerson, wine which is a staple of Hafiz's poetry, is a symbol of intellectual freedom (Works, V, 258). Hafiz helped Emerson to break up the tiresome old roof of heaven into new forms. He loved Hafiz. In his writings about Persian poets, Emerson includes Hafiz among the seven masters of the Persian Parnassus, Ferdowsi, Enveri, Nizami, Dschelaleddin, Saadi, Hafiz, and Dschami" (Soucek, 2003).

In "The Aesthetic of Influence", Guillen describes literary influence and says "no student or theorist of influence denies that literature breeds literature" for the reason that "certain textual correspondences are not the product of chance" but of influence. What Guillen considers as influence either is a conscious borrowing from one author by another, or it is "an echo proceeds from an involuntary reminiscence, of which the author was not aware until several years after he had written the poem". The latter form of influence constitutes "the sum of elements preserved in the memory or the sensibility of the poet before the genesis of a particular poem begins." On the other hand, Guillen makes a distinction between parallelism and influence (Guillén, 2015).

This is for the reason that Guillen considers influence "a recognizable and significant part of the genesis of a literary work of art". Consequently, studies of literary influence cope with "the genesis of a work of art," that is to say, of the growth of a literary work more willingly than with sheer thematic or other literary fundamentals of connection. As for the intention of comparative studies, Guillen believes that "the discovery of influence does not modify our appreciation or evaluation of a poem [and the] phenomenon has precious little to do with any absolute scale of aesthetic values or broad survey of literary achievements". Rather, the study of influence tries to make "a value judgment not measure a fact. The 
critic must evaluate the function or the scope of the effect of A on the making of B". Besides, the study of influence should never consider borrowing as inferior because comparative studies of influence examine the recipient's contribution to the works of their precursor (Guillén, 2015).

The correspondences between the poetry of Emerson and Hafiz surpass simple accidental similarities. First, let us consider the poets, their schools of poetry and their backgrounds. Hafiz was born in Shiraz in 1389; Emerson in Concord in 1803. Hafiz was a classic poet; Emerson is a modern poet. Hafiz was born in a Muslim country; Emerson in a Christian one. Emerson led the Transcendentalist movement of the mid-19th century. He was seen as a champion of individualism and a prescient critic of the countervailing pressures of society, and he disseminated his thoughts through dozens of published essays and more than 1,500 public lectures across the United States. Emerson gradually moved away from the religious and social beliefs of his contemporaries, formulating and expressing the philosophy of Transcendentalism in his 1836 essay, Nature. Themes of Hafiz's ghazals are the beloved, faith, and exposing hypocrisy. His poetry is influenced by Islam. He was a poet of didactic, ecstatic mysticism (Roozbeh, 2018).

Emerson's first source of reading Hafiz was Goethe's West-Eastern Divan. Emerson's first real contact with Goethe was his perusal of Wilhelm Meister in 1828, in Carlyle's translation. He didn't start learning to read German until 1836, and never read more than passingly well. He owned a 55-volume edition of Goethe's works and read many of them in the original. Goethe was a lifelong influence, and in Representative Men, Emerson's essay on Goethe was titled "Goethe, or, the Writer". Emerson granted Goethe a position near the very top of mankind. Goethe's West-Eastern Divan was not merely a translation of Hafiz, rather it consisted of the themes he found in the poetry of Hafiz. He interjected Persian terminology in his poetry so as to communicate a fair idea of what Hafiz was set to in his work. Definitely his work can be considered as the title itself says as combination of the Occident and the Orient. It consisted of twelve books all with Persian words: MoqqaniNameh or Book of the Singer, Hafiz-Nameh or Book of Hafiz, Eshq-Nameh or Book of Love, Tafakkor-Nameh or Book of Reflection, Rind-Nameh or Book of Ill Humour, Hikmat-Nameh or Book of Maxims, Timur-Nameh or Book of Timur, Zuleika-Nameh or Book of Zuleika, Saki-Nameh or Book of the Cupbearer, Matal-Nameh or Book of Parables, Parsi Nameh or Book of the Persian and Khuld-Nameh or Book of Paradise. Gautier's masterpiece put Hafiz on a pedestal in the west. Goethe believed that it was now time he visualized a humane international philosophy with no attention to nationality and dogma and that the East and the West were not disconnected from each other. Goethe used such terms as 'Saint Hafiz' and 'Celestial Friend' in addressing Hafiz (Roozbeh, 2018). The poetry of Hafiz stirred up tremendous enthusiasm in Goethe so that he addressed him in his Divan over and over again. It was as if the two great poets had combined in spirit and had become brothers (Islam, 1973). Emerson read Goethe a lot. For him Goethe was a great poet whom he adored. This great poet of German culture adored Hafiz a lot and when Emerson observed that Goethe considered himself small in comparison to Hafiz, Emerson came to recognize the richness of Hafiz (Nasr, 1972).

In 1846, Emerson came upon the translation of Von Hammer-Purgstall's German translation. Richard Lee Francis starts his article Archangel in the Pleached Garden, Emerson's Poetry as follows 'in April of 1846, in Elizabeth Peabody's bookstore in Boston, Emerson discovered and purchased the two volume German translation of the Divan of the 
Persian poet, Hafiz. Emerson, with his rudimentary German, was attracted both by the exotic subject matter and by the poet's treatment of it, which was at once highly intellectual and highly sensual (Roozbeh, 2018).

Emerson read Hammer's translation. He owed his familiarity with Hafiz in particular and Persian poets in general to Hammer as he himself says: to Baron von Hammer Purgstall, we owe our best knowledge of the Persians (Emerson, 2010). He has translated into German, besides the "Divan" of Hafiz, specimens of two hundred poets, who wrote during a period of five and a half centuries, from A.D.1000 to 1550. The primary sources of his knowledge of Persian poetry were the two volumes of German translations published by Joseph von Hammer Purgstall in the early nineteenth century (Reaver, 1980).

In the eighteenth century many western thinkers, poets, and writers became interested in Hafiz. One such thinker was Sir William Jones who translated a few poems of Hafiz in 1771. He was a scholar and a lawyer who allegedly knew twenty-eight languages. Jones was the father of Persian studies in the west. He introduced Hafiz to the literary world of London and Europe. Jones believes that Hafiz's poetry is reminiscent of that of Petrarch. For both poets, the lover is resisting, cruel but beautiful. Nevertheless, Jones does not exclude the possible mystical interpretation of Hafiz's poetry. To him, the poetry of Hafiz is a form of meditation on divine perfection. He translated and annotated the first ghazals of the Divan of Hafiz titled A Persian Song of Hafiz (Jafri, 2000).

Of Hafiz he says "Hafiz is the prince of Persian poets, and in his extraordinary gifts adds to some of the attributes of Pindar, Anacreon, Horace, and Burns the insight of a mystic, that sometimes affords a deeper glance at Nature than belongs to either of these bards. He accosts all topics with an easy audacity". Therefore because of his love for Hafiz, Emerson thinks it obligatory to translate Persian poets from German to American. He reads and reads Hafiz until he becomes an expert of Hafiz so much so that he passes commentary on Hafiz and enumerates Hafiz's “merits” (Emerson, 1971).

Of the merits of Hafiz, Emerson says: He was the fluent mind in which every thought and feeling came readily to the lips. "Loose the knots of the heart," he says. We absorb elements enough, but have not leaves and lungs for healthy perspiration and growth. An air of sterility, of incompetence to their proper aims, belongs to people who have both experience and wisdom. But a large utterance, a river, that makes its own shores, quick perception and corresponding expression, a constitution to which every morrow is a new day, which is equal to the needs of life, at once tender and bold, with great arteries,--this generosity of ebb and flow satisfies, and we should be willing to die when our time comes, having had our swing and gratification. The difference is not so much in the quality of men's thoughts as in the power of uttering them. What is pent and smouldered in the dumb actor is not pent in the poet, but passes over into new form, at once relief and creation (Emerson, 2010).

He goes on to discuss Hafiz's other merits. The other merit of Hafiz, says Emerson, is his intellectual liberty, which is a certificate of profound thought. The phrases 'intellectual liberty' and 'profound thought' are key phrases in Emerson's understanding Hafiz's poetry. He loves Hafiz because hypocrisy is the perpetual butt of his arrows. From Hafiz he learns that not the dervish, or the monk, but the lover, has in his heart the spirit which makes the ascetic and the saint; and certainly not their cowls and mummeries (Emerson, 2010). Why does Emerson like this cast of mind of Hafiz? Rosán answers the spirit of our age has been forcing many modern idealists, together with Emerson and Thoreau, to look wistfully toward other cultural areas for inspiration (Rosán, 1952). 
One of these cultures is on the part of Ralph Waldo Emerson Persian culture and for that matter Hafiz's poetry. And Hafiz's poetry undoubtedly caught Emerson's attention because it reflected some of his own poetical concerns at the time. According to Francis, to Emerson's poems is that tension in Hafiz between philosophical illumination and sensual delight; for a similar tension haunted Emerson's whole artistic career (Francis, 1966). Colapietro writes: through Goethe and other German authors Emerson became acquainted with classical Persian poetry, an immense influence on his intellectual life (Colapietro, 2004). Guillen says Emerson was struck by the name Hafiz. The Persian word, he noted, "signifies one gifted with so good a memory that he knows the whole Quran by heart (Guillén, 2015). Knowing the Quran by heart, however, does not make one its slave. Quite the contrary. For Hafiz, an intimate knowledge of the Quran was also the beginning of a contrapuntal poetics: revealed religion turned into human speech, a heaven-bent teleology turned into the cumulative time of a long-lived species. Poetry, as exemplified by Hafiz, is a kind of negative extension of the Quran, a heresy sometimes reckless and flaunting, sometimes not, but always giving him a path oblique to, tangential to, and thus not containable by Islam. This heresy has now been passed on to Emerson. He revels in it in one of his drafted translations, The very wind pipes rowdy songs, 'Drives sober people mad', 'Makes saints and patriarchs bad', 'Should', 'Shall we suffer', 'tolerate such wrongs' And, 'not give the alarm', 'cry out like mad' 'makes saints perverse', 'makes' angels bad (Dimock, 2001).

Frederic Carpenter indicates that Emerson loved both Hafiz and Saadi because they were joyful. And they were joyful because, trusting in themselves and in the fullness of life, and they had escaped from the ambush of fatalism (Carpenter, 1939). Len Gourgeon points out that Emerson comments in 1847, such is the only "man" I wish to see and to be. The man in this quotation is Hafiz whom Emerson wishes to be like (Gougeon, 1989). J. Russell Reaver in his article entitled "Emerson's Focus in "The Conduct of Life" points out that the references to Buddha, Hafiz, the Vishnu Sarma, and Mahomet broaden Emerson's Occidental perspective and echo the essence of Oriental spiritual autonomy in his Brahma (Reaver, 1980).

Emerson changed his view about the east because of his familiarity with eastern philosophers and poets. Scorza writes unlike Aristotle, Emerson had the opportunity to immerse himself in Islamic, Buddhist, Hindu, Confucian, and other non-Western writings, and can acknowledge significant intellectual debts outside of the Western tradition. For instance Emerson asserts that certain Eastern poets, among them Ibn Jemin, Hafiz, and Jami, make contributions to the philosophy of friendship equal to that of Montaigne. Scorza goes on to say similarly, one of Emerson's more famous observations concerning friendship, $\mathrm{He}$ will have learned the lesson of life who is skilful in the ethics of friendship, is based on a quotation from Hafiz, "Thou learnest no secret until thou knowest friendship, since to the unsound no heavenly knowledge enters (Scorza, 2004).

Massud Farzan also confesses the indebtedness of Emerson to Hafiz 'his contemporary kindred soul Emerson was extremely interested in the Sufis, having read their works extensively and written about them, notably Saadi and Hafiz. Similarly, Steven B Hermann points out "that Emerson was simultaneously translating a ghazal by the Persian and Sufi poet Hafiz, where Emerson was deeply taken with the couplet 'Take my heart in thy hand, O beautiful boy of Shiraz!' (Farzan, 1976). Mr. Dowdeswell took for his subject the Persian poet, Hafiz, who lived and died in the fifteenth century, and concerning the inner meaning of whose poems Goethe, Emerson, and many other thoughtful writers have left to 
posterity more or less contradictory opinions (Yoder, 1972). Schroeder argues that two of the foremost Western minds needed little persuasion of the value of the poet (Hafiz). Emerson was one, and the other one is Goethe. The latter is of particular interest, not only because of the characteristically prophetic or universal quality of his understanding, but because of the clarity of his introspection. Schroeder believes that what makes Hafiz worth an American poet's study is a music of meaning beyond the music of the words, a richness of which Emerson was aware when he called Hafiz a fact-book which all geniuses prize as raw material and as antidote to verbiage and false poetry (Welch, 1969). Yoder apropos of the development of Emerson's poetic style writes Emerson looked then to other sources that corroborated his ideas about poetic freedom, mainly to older traditions, the poetry of Saadi and Hafiz, the Vedas, and the ancient British bards (Yoder, 1972).

\section{Methodology}

Two different poems were chosen as the materials of the study. The first one is 'Bacchus' which is song by Emerson. The reason to choosing this poem is that among the poems of Emerson all reviewers unanimously accepted that as the surest indication of the trace of Hafiz in Emerson. And the next one is 'Saqi-Nameh' whish song by Hafiz and its reason is that this poem is translated by Emerson. Following we can read the poems:

\section{a. Bacchus}

Bring me wine, but wine which never grew,

In the belly of the grape, we buy diluted wine,

Give me of the true, whose ample leaves and tendrils curled,

Among the silver hills of heaven,

Draw everlasting dew, Wine of wine,

That I intoxicated,

And by the draught assimilated,

May float at pleasure through all natures,

The bird-language rightly spell,

And that which roses say so well,

Wine that is shed,

Like the torrents of the sun up the horizon walls,

Water and bread,

Food which needs no transmuting,

Rainbow-flowering, wisdom-fruiting, Wine which is already man,

Food which teach and reason can,

Wine which Music is, Music and wine are one,

that I, drinking this,

Shall hear far Chaos talk with me,

Kings unborn shall walk with me,

Quickened so, will I unlock,

Every crypt of every rock,

Pour, Bacchus! The remembering wine,

Retrieve the loss of men and mine,

Haste to cure the old despair,

Reason in Nature's lotus drenched, 
the memory of ages quenched,

Give them again to shine,

A dazzling memory revive,

Refresh the faded tints,

Recut the aged prints,

And write my old adventures with the pen,

Which on the first day drew,

Upon the tablets blue,

The dancing Pleiads and eternal men.

\section{Saqi-Nameh of Hafiz I}

Butler, fetch the ruby wine,

Which with sudden greatness fills us,

Pour for me who in my spirit,

Fail in courage and performance,

Bring the philosophic stone, Karun's treasure,

Noah's life; Haste, that by thy means,

I open All the doors of luck and life,

Bring me, boy, the fire-water Zoroaster sought in dust,

To Hafiz revelling 'tis allowed,

To pray to Matter and to Fire,

Bring the wine of Jamschid's glass,

That shone, ere time was, in the Neat,

Give it me, that through its virtue,

I, as Jamschid, see through worlds,

Wisely said the Kaiser Jamschid,

This world's not worth a barleycorn,

Bring me, boy, the nectar cup,

Since it leads to Paradise,

Flute and lyre lordly speak,

Lees of wine outvalue crowns,

Hither bring the veiled beauty,

Who in ill-famed houses sits,

Lead her forth: my honest name,

Freely barter I for wine,

Bring me, boy, the fire-water,

Drinks the lion - the woods burn,

Give it me, that I storm heaven,

Tear the net from the arch-wolf,

Wine, wherewith the Houris teach,

Angels the ways of Paradise,

On the glowing coals I'll set it,

And there with my brain perfume,

Bring me wine, through whose effulgence,

Jam and Chosroes yielded light,

Wine, that to the flute I sing,

Where is Jam, and where is Kauss,

Bring the blessing of old times,

Bless the old departed Shahs,

Bring it me, the Shah of hearts, 
Bring me wine to wash me clean,

Of the weather-stains of care,

See the countenance of luck,

While I dwell in spirit-gardens,

Wherefore sit I shackled here?

Lo, this mirror shows me all,

Drunk, I speak of purity, Beggar,

I of lordship speak,

When Hafiz in his revel sings,

Shouteth Sahra in her sphere,

Fear the changes of a day,

Bring wine which increases life,

Since the world is all untrue,

Let the trumpets thee remind,

How the crown of Kobad vanishedm,

Be not certain of the world,

'Twill not spare to shed thy blood,

Desperate of the world's affair,

Came I running to the wine-house,

Give me wine which maketh glad,

That I may my steed bestride,

Through the course career with Rustem,

Gallop to my heart's content,

Give me, boy, the ruby cup,

Which unlocks the heart with wine,

That I reason quite renounce,

And plant banners on the worlds.

Let us make our glasses kiss,

Let us quench the sorrow-cinders,

To-day let us drink together,

Whoso has a banquet dressed,

Is with glad mind satisfied,

'Scaping from the snares of Dews.

Give me wine, that I o'erleap,

Both worlds at a single spring,

Stole at dawn from glowing spheres,

Call of Houris to mine ear,

O happy bird! delicious soul,

Spread thy pinion, break the cage,

Sit on the roof of the seven domes,

Where the spirit takes repose,

In the time of Bisurdschimihr,

Menutscheher's beauty shined,

On the beaker of Nushirvan,

Wrote they once in eider times,

Hear the Counsel, learn from us,

Sample of the course of things,

Earth, it is a place of sorrow,

Scanty joys are here below,

Who has nothing, has no sorrow, 
A cup of wine imparts the sight,

Of the five heaven-domes with nine steps,

Give me, boy, the Kaiser cup,

Which rejoices heart and soul,

Empty sorrows from the earth,

Canst thou drive away with wine,

\section{b. Procedure}

The poems were selected as already described in materials section. The researcher began with a fully-attentive watching of the poems to see if Emerson was influenced by Hafiz or not based on Claudio Guillen's comparative literary theory of influence which belongs to French school of comparative analysis. Guillen's theory reinforces the study because it defines the attributes of literary influence; it also functions as a yardstick for assessing the contribution of the recipient of influence to his national literature and to the work of his precursor. To reach this, the researcher compared completely two poems which are song by two different people from two different countries, cultures, ethics, thoughts, periods, and so on, verse by verse and their meaning too. The reason to choosing Emerson is that he was himself a translator of Hafiz and the Persian poems that researcher will study here are the translations of Emerson himself because he found him great and as we said before he also passed comments and in point of fact registers the results of his reading Hafiz in German. In actuality due to passing judgment on Hafiz we can call him a scholar of Hafiz.

\section{Discussion}

As mentioned in the previous section, the data for this study were collected through comparing the poems written by Hafiz and Emerson. This helps to find the differences between Hafiz and Emerson thoughts and interests. The researcher aimed to find if Emerson was influenced by Hafiz or not. To do that researcher compared completely the two poems song by Hafiz and Emerson and paid attention to their meaning and aimed to know what are the differences and similarities between their way of thinking, by using that reach to the influences of the Hafiz on the Emerson.

The poem's beginning resembles the beginning of Hafiz's poem in that both speakers, in the poems, attempt to invoke the person or the goddess associated with wine. Both poems commemorate wine. Both poems look upon wine as more than simply the sheer juice of the grape. They both perceive in it the power of liberating the mind to new ecstasies and insight, and relieving it of despair. Both speakers are looking for true wine.

This is the fact that true wine is one of the staple of Hafiz's poetry which Hafiz talks about in his poems. In Hafiz mind, wine is something different from what people drink and this is true about Emerson too. He does not mean the wine we see in the market. In fact Emerson means something which Hafiz had in mind. According to Emerson wine of Hafiz is not to be confounded with vulgar debauch. It is the spirit in which the song is written that imports, and not the topics. Hafiz praises wine, to give vent to his immense hilarity and sympathy with every form of beauty and joy; and lays the emphasis on these to mark his scorn of sanctimony and base prudence. This true wine in Hafiz is called sharabe naab or meye naab (true wine). This theme is greatly Hafizean and appears several times in Hafiz. If we peruse the Divan of Hafiz, we see that this theme is repeated eight times. What Hafiz wishes for in terms of drink is something divine and true like what Emerson wishes for in the 
above lines most especially in lines one and two "wine which never grew in the belly of the grape. Wine of Emerson is neither to be confounded with vulgar debauch. In Emerson too wine is "the spirit in which the song is written that imports, and not the topics". As in Hafiz wine gave vent to his immense hilarity and sympathy with every form of beauty and joy; and lays the emphasis on these to mark his scorn of sanctimony and base prudence, the same is true in Emerson again.

Structurally the peculiarity of the syntax in Bacchus is reminiscent of Hafiz's poetry in that both poems are imperative in tone. This is reflected, for example, in action verbs of 'bring', pour', and 'give'. Both poems start with an apostrophe. In Hafiz's poem wine is a motif as it is in Emerson. Yohanan believes that there are similarities of diction: 'heaven', 'world', 'reason', 'unlock', 'quench' are words to be found in both passages (Yohannan, 1943b). In the one, reason is renounced; in the other, it is in nature's lotus drenched. In the one, the 'sorrow cinders' are quenched; in the other, the memory of ages quenched. Emerson's 'kings unborn shall walk with $m e^{\prime}$ is a match for the actual names of Persian king (shahs) paraded by Hafiz; and the both worlds which Hafiz would 'O'erspring at a single leap' are mentioned, though under a different figure, in Emerson's last line.

What is significant regarding the poem of Emerson is that the rhyme of the poem has a certain awkwardness which we will explore. If we have a look at the following two lines which researcher spotted in the poem, we can see that the rhyme of the two lines is unlike any other American versification in that rhyme. American poetry appears at the end of each line in not the middle. What's more nowhere in American poetry do we see the repetition of two or more similar words at the end of the poem following rhyme. For example if we see that some words are repeated at the end of each line, so this is something awkward in American poetry. We may ask why that is so. The answer lies in the Persian poetry in general and Hafiz's poetry in particular where we see the repetition of two or more identical words at the end of the poem following rhyme. In Persian poetry we have something called radif which is the repetition of two or more identical words at the end of the poem following rhyme. Radif is something missing in American poetry. Structurally Emerson is following Persian poetry. It should also be mentioned that in English poetry we have something called anaphora which is the deliberate repetition of a word or phrase at the beginning of each one of a sequence of sentences, paragraphs, lines of verse, or stanzas (Tavakoli-Targhi, 1990).

Another important parallel in Hafiz and Emerson is the washing of a part of the body with wine. In Hafiz it is washing the whole body but in Emerson it is the washing the eyes. In fact washing some part of the body with wine may sound ridiculous to the reader but as we said before this is not juicy grape of wine but rather divine wine in which Hafiz wishes to bathe. Emerson following Hafiz uses this imagery to convey the same attitude towards wine and be purified with wine of providence.

Clearly, Emerson is dealing with much similar basic material; and equally noticeably, he has found Hafiz's techniques to give beneficial insights into ways of coping with his own material. The influence of Hafiz can be seen in other details and in other of Emerson's works 'To J.W'.

\section{Conclusion}

By the previous results and discussion we can see that no one can really deny the fact that Emerson was influenced by Hafiz, especially when we read from Emerson himself 
saying of Hafiz that: such is the only man I wish to see and to be. This statement means a lot and can prove many things. In point of fact without setting the works of the two writers over each other to find the influence of Hafiz on Emerson, this statement itself is suffice and clarifies the extent of Hafiz's influence on Emerson's poetry. It means that Emerson indulged himself in the works of this Persian poet, it means that Emerson appreciated this poet among the whole range of poets he came across. As a result, he is the best poet in Emerson's point of view and it means above all Emerson was influenced by Hafiz a lot. This fact is endorsed especially when we see Emerson called Hafiz "the prince of all poets".

In order to give an idea of the kind of cultural influence that Eastern poetic art is having on the poetry of Ralph Waldo Emerson, researcher tried to give some idea of the distinctly American foundations upon which this influence is being brought to bear. Obviously, Emerson is dealing with much different basic material, but equally obviously, he has found Hafiz's techniques to offer constructive insights into ways of dealing with his own material. The influence of Hafiz can be seen in other details and in other of Emerson's works, some of which I have dealt with in this essay. As to the effect of this new movement on American poetry as a whole, there is no doubt that it is undergoing revolutionary changes. The few works examined in this study should demonstrate the accuracy of this judgment.

\section{References}

Adkins, N. F. (1948). Emerson and the Bardic Tradition. Publications of the Modern Language Association of America, 662-677.

Carpenter, F. I. (1939). William James and Emerson. American Literature, 11(1), 39-57.

Colapietro, V. (2004). Confronting the Actuality of History: Re-Interpreting Miller in Light of Douglas Anderson, John E. Smith, and Cushing Strout. Transactions of the Charles $S$. Peirce Society, 40(2), 213-228.

Dimock, W. C. (2001). Deep Time: American Literature and World History. American Literary History, 13(4), 755-775.

Emerson, R. W. (1971). The Collected Works of Ralph Waldo Emerson: Society and Solitude (Vol. 7): Harvard University Press.

Emerson, R. W. (2010). Collected Works of Ralph Waldo Emerson, Volume VIII: Letters and Social Aims: Harvard University Press.

Farzan, M. (1976). Whitman and Sufism: Towards" A Persian Lesson". American Literature, 47(4), 572-582.

Francis, R. L. (1966). Archangel in the Pleached Garden: Emerson's Poetry. ELH, 33(4), 461-472.

Gougeon, L. (1989). Emerson, poetry, and reform. Modern Language Studies, 38-49.

Guillén, C. (2015). Literature as system: essays toward the theory of literary history (Vol. 1449): Princeton University Press.

Islam, S. (1973). The Influence of Eastern Philosophy on Yeats's Later Poetry. Twentieth Century Literature, 19(4), 283-290.

Jafri, S. (2000). Hafiz Shirazi. Source: Social Scientist, 28(1/2), 12-31.

Nasr, S. H. (1972). Conditions for meaningful comparative philosophy. Philosophy East and West, 22(1), 53-61.

Reaver, J. R. (1980). Emerson's Focus in" The Conduct of Life". South Atlantic Bulletin, 45(4), 78-89. 
Roozbeh, R. (2018). Hafiz Shirazi in America: Ralph Waldo Emerson. World Scientific News, 94(2), 173-189.

Rosán, L. J. (1952). A key to Comparative Philosophy. Philosophy East and West, 2(1), 56-65.

Scorza, J. A. (2004). Liberal citizenship and civic friendship. Political theory, 32(1), 85-108.

Soucek, P. (2003). Interpreting the ghazals of Hafiz. RES: Anthropology and Aesthetics, 43(1), 146-163.

Tavakoli-Targhi, M. (1990). Refashioning Iran: language and culture during the constitutional revolution. Iranian Studies, 23(1-4), 77-101.

Welch, S. C. (1969). Eric Schroeder: JSTOR.

Yoder, R. A. (1972). Toward the" Titmouse Dimension": The Development of Emerson's Poetic Style. Publications of the Modern Language Association of America, 255-270.

Yohannan, J. D. (1943a). Emerson's translations of Persian poetry from German sources. American Literature, 14(4), 407-420.

Yohannan, J. D. (1943b). The influence of Persian poetry upon Emerson's work. American Literature, 15(1), 25-41. 